\title{
Cloning of bovine parathyroid hormone-related protein (PTHrP) cDNA and expression of PTHrP mRNA in the bovine mammary gland
}

\section{S F Wojcik, F L Schanbacher ${ }^{1}$, L K McCauley ${ }^{2}$, H Zhou ${ }^{3}$, V Kartsogiannis ${ }^{3}$, C C Capen and T J Rosol}

Department of Veterinary Biosciences, College of Veterinary Medicine, The Ohio State University, Columbus, Ohio, USA

${ }^{1}$ Department of Animal Sciences, Ohio Agricultural Research and Development Center, The Ohio State University, Wooster, Ohio, USA

${ }^{2}$ Department of Periodontics, Prevention, and Geriatrics, University of Michigan, Ann Arbor, Michigan, USA

${ }^{3}$ Department of Medicine, University of Melbourne, St Vincent's Hospital, Melbourne, Victoria, Australia (Requests for offprints should be addressed to T J Rosol)

\begin{abstract}
Parathyroid hormone-related protein (PTHrP) produced by the mammary gland has been postulated to have multiple functions in both the mother and neonate. In humans, alternative $3^{\prime}$-mRNA splicing and endoproteolytic processing result in multiple bioactive PTHrP peptides. Multiple PTHrP peptides also have been reported in bovine milk. To investigate the source of molecular heterogeneity of PTHrP in bovine milk, bovine PTHrP was cloned from a bovine brain cDNA library, sequenced and used to characterize the mammary PTHrP transcript. A 1065 bp clone (bP1) for bovine PTHrP was isolated from a brain cDNA library. The bP1 clone contained the entire coding sequence of PTHrP and 61 and 473 nucleotides of the $5^{\prime}$ - and $3^{\prime}$-untranslated regions (UTRs) respectively. The predicted amino acid sequence of bovine PTHrP was $72-92 \%$ homologous to the sequences of chicken, rat, mouse,
\end{abstract}

human, and canine PTHrP with the highest sequence divergence present in the $\mathrm{C}$-terminal region of the peptide. The $5^{\prime}$ - and $3^{\prime}$-UTRs of bovine brain PTHrP have a high degree of homology to exons 4 and 9 of human PTHrP respectively. PTHrP was expressed as a single 1200 nucleotide mRNA transcript in lactating bovine mammary tissue. RTPCR using region-specific oligonucleotide primers derived from bP1 demonstrated that PTHrP mRNA transcripts in bovine brain and lactating mammary gland utilize the same $5^{\prime}$ - and $3^{\prime}$-UTRs. Expression of PTHrP mRNA was localized to secretory and ductular epithelial cells within the lactating mammary gland, as detected using in situ hybridization. Expression of PTHrP mRNA was demonstrated in the mammary gland during late pregnancy and throughout lactation in cows.

Fournal of Molecular Endocrinology (1998) 20, 271-280

\section{INTRODUCTION}

Parathyroid hormone-related protein (PTHrP) was initially identified as a product of human and animal tumors associated with humoral hypercalcemia of malignancy (Suva et al. 1987, Rosol \& Capen 1992). Subsequently, the expression of PTHrP mRNA and protein has been reported in other neoplasms as well as many normal fetal and adult tissues in both animals and humans, including the mammary gland (Ikeda et al. 1988, Thiede \& Rodan 1988, Liapis et al. 1993).
PTHrP is produced in the mammary gland during late pregnancy and lactation and is postulated to have multiple effects in the mammary gland as well as the neonate, including regulation of calcium transport, relaxation of smooth muscle, and regulation of cell growth and differentiation (Ratcliffe 1992, Thiede 1994). In addition, overexpression of PTHrP in the mammary gland of transgenic mice impaired branching morphogenesis of ducts during prepubertal development as well as lobuloalveolar development during pregnancy, supporting a physiologic role for PTHrP in 
mammary gland morphogenesis (Wysolmerski et al. 1995).

PTHrP has been demonstrated in the milk of multiple species including human, bovine, rat, and goat where concentrations of PTHrP in milk are 1000-10 000-fold higher than the concentrations observed in maternal blood (Thiede \& Rodan 1988, Budayr et al. 1989, Khosla et al. 1990, Ratcliffe et al. 1992, Kocabagli et al. 1995). Multiple bioactive PTHrP peptides have been identified in both human and bovine milk. In humans, these peptides are thought to arise from endoproteolytic processing of PTHrP as well as alternative splicing of PTHrP mRNA, which results in three different isoforms of PTHrP that differ in their $\mathrm{C}$ terminus. Three different PTHrP mRNA transcripts have been demonstrated in human breast tumors and, more recently, in normal lactating human mammary tissue (Southby et al. 1995, Andersson et al. 1997). The biologic significance of the different PTHrP isoforms has not been established. Alternative splicing of PTHrP mRNA transcripts has not been demonstrated in the rat, mouse, or chicken. The expression of PTHrP mRNA in the mammary tissue of bovines has not been previously reported.

In the present study, we describe the cloning and sequencing of bovine PTHrP cDNA. The cDNA sequence and the predicted amino acid sequence for bovine PTHrP were compared with genomic DNA and deduced amino acid sequences of multiple species. The bovine mammary PTHrP mRNA transcript was characterized and the temporal expression of PTHrP mRNA within the bovine mammary gland was investigated. In addition, in situ hybridization was used to localize P'THrP mRNA expression within lactating bovine mammary tissue.

\section{MATERIALS AND METHODS}

\section{Cloning and sequencing of bovine PTHrP cDNA}

A 434 bp bovine PTHrP cDNA probe was generated by RT-PCR from total RNA isolated from bovine hypothalamus using primers derived from the coding and $3^{\prime}$-UTR of human PTHrP corresponding to amino acids 6-12 (5'-CAG CTC CTC CAT GAC AAG GGG-3') of the mature peptide and nucleotides 6-25 (5'-CCT TGG AAG GTC TCT GCT GA-3') in the $3^{\prime}$-UTR, for the sense and antisense primers respectively. The bovine PTHrP cDNA probe was labeled with $\alpha-\left[{ }^{32} \mathrm{P}\right] \mathrm{dATP}$ using a random primer labeling kit (Gibco-BRL, Gaithersburg, MD, USA) and used to screen approximately $5 \times 10^{5}$ plaques of a bovine brain cDNA library prepared in phage $\lambda$ UNI-ZAP XR (Stratagene Cloning Systems, La Jolla, CA, USA). Hybridization was carried out overnight at $42{ }^{\circ} \mathrm{C}$ in $2 \times$ PIPES, $50 \%$ formamide, $0 \cdot 5 \%$ SDS, and salmon sperm DNA at $100 \mu \mathrm{g} / \mathrm{ml}$. After washing at $60{ }^{\circ} \mathrm{C}$ in $0 \cdot 1 \times \mathrm{SSC}$ and $0.1 \%$ SDS for $1 \mathrm{~h}$, the membranes were exposed to $\mathrm{X}$-ray film overnight at $-80{ }^{\circ} \mathrm{C}$. Putative clones were selected and rescreened until individual plaques were isolated. Plasmid DNA (pBluescript) from positive clones was isolated and a positive clone with an insert of greater than $1 \mathrm{~kb}$ (designated bP1) was further characterized. Both strands were sequenced using an Applied Biosystems Model 373A DNA Sequencer (Applied Biosystems, Foster City, CA, USA). Internal oligonucleotide primers for stepwise sequencing were synthesized commercially (Integrated Data Technologies, Coralville, IA, USA).

\section{Tissue procurement}

Normal mammary tissue from 17 heifers and cows was obtained within $15 \mathrm{~min}$ of killing, frozen in liquid nitrogen, and stored at $-80{ }^{\circ} \mathrm{C}$ until RNA isolation. Samples included normal mammary tissue from non-pregnant heifers, heifers pregnant with their first calf, and adult cows in various parities and stages of lactation as listed in Table 1.

\section{RNA isolation}

Total RNA was extracted using RNAzol B (Tel-Test, Inc., Friendswood, TX, USA) or Trizol (Gibco-BRL), quantitated, and stored in Formazol (Molecular Research Center, Inc., Cincinnati, OH, USA) at $-80{ }^{\circ} \mathrm{C}$. Messenger RNA was isolated from total RNA by incubating with oligo-dT cellulose, and washing and eluting retained poly (A)+ RNA using the Fast Track mRNA isolation kit (InVitrogen, San Diego, CA, USA).

\section{Northern blot hybridization}

Total RNA or poly (A)+ mRNA $(10-30 \mu \mathrm{g})$ was separated by gel electrophoresis in a $1.2 \%$ agarose/ $2 \cdot 2 \mathrm{M}$ formaldehyde gel and transferred overnight to a nylon membrane (Duralon UV, Stratagene) in $20 \times$ SSC. The membrane was incubated in prehybridization solution $(50 \%$ formamide, $5 \times \mathrm{SSC}$, $10 \mathrm{mM}$ Tris- $\mathrm{HCl}(\mathrm{pH} \quad 7 \cdot 5), 125 \mu \mathrm{g} / \mathrm{ml}$ salmon sperm DNA, $1 \times$ Denhardt's solution, $0 \cdot 2 \%$ SDS and $1 \%$ background quencher (Molecular Research Center, Inc.)) for $2 \mathrm{~h}$ at $42{ }^{\circ} \mathrm{C}$. $\left[{ }^{32} \mathrm{P}\right] \mathrm{dATP}$-labeled $434 \mathrm{bp}$ bovine PTHrP cDNA probe was added and hybridization was continued overnight at $42{ }^{\circ} \mathrm{C}$. 
TABLE 1. Animals used in the study

\begin{tabular}{|c|c|c|c|c|}
\hline & Breed & $\begin{array}{l}\text { Age } \\
\text { (years) }\end{array}$ & Stage of lactation & PTHrP mRNA expression \\
\hline 1 & Holstein & 1 & Non-pregnant, non-lactating & Negative \\
\hline 2 & Charolais & 2 & 6 months pregnant, non-lactating & Positive \\
\hline 3 & Holstein & 3 & 7 months pregnant, non-lactating & Negative \\
\hline 4 & Holstein & 9 & 3 days postpartum, lactating & Positive \\
\hline 5 & Holstein & 3 & 2 weeks postpartum, lactating & Positive \\
\hline 6 & Holstein & 4 & 2 weeks, postpartum, lactating & Positive \\
\hline 7 & Brown Swiss & 3 & 3 weeks postpartum, lactating & Negative \\
\hline 8 & Holstein & 5 & 2-4 weeks postpartum, lactating & Positive \\
\hline 9 & Holstein & 2 & 1 month postpartum, lactating & Positive \\
\hline 10 & Holstein & 4 & 1 month postpartum, lactating & Positive \\
\hline 11 & Holstein & 7 & 1 month postpartum, lactating & Positive \\
\hline 12 & Holstein & 5 & 4 months postpartum, lactating & Positive \\
\hline 13 & Holstein & 3 & 6 months postpartum, lactating & Positive \\
\hline 14 & Holstein & 7 & 13 months postpartum, lactating & Positive \\
\hline 15 & Holstein & 4 & 18 months postpartum, lactating & Positive \\
\hline 16 & Holstein & 3 & 60 days non-lactating, 9 months pregnant & Positive \\
\hline 17 & Holstein & 4 & 365 days non-lactating, 4 months pregnant & Negative \\
\hline
\end{tabular}

The membrane was washed in $1 \times \mathrm{SSC}$ and $0 \cdot 1 \%$ SDS at $50{ }^{\circ} \mathrm{C}$ for $1 \mathrm{~h}$ and exposed to X-ray film overnight at $-80{ }^{\circ} \mathrm{C}$. Total RNA $(10 \mu \mathrm{g})$ isolated from a canine apocrine adenocarcinoma associated with humoral hypercalcemia of malignancy was used as a positive control for PTHrP (Rosol et al. 1990).

\section{Oligonucleotide primers}

Oligonucleotides used to detect PTHrP mRNA expression in bovine mammary tissue by RT-PCR were derived from $\mathrm{bP} 1$ and the published sequence of human PTHrP (Fig. 1). To amplify the coding region of $\mathrm{PTHrP}$, one of two primer pairs was used: primers P1 (5'-CAg TGG AGC GTC GCg GTG TTC-3'; mismatches shown in lower case) and P11 (5'-GTA cGT CTC CAC CTT GTT-3'; mismatches shown in lower case) which amplify a fragment of $320 \mathrm{bp}$, or primers $\mathrm{P} 1$ and $\mathrm{P} 57$ (5'-GAG TTG AGC TCC AGC GAT-3') which amplify a fragment of $499 \mathrm{bp}$. Region-specific oligonucleotide primers derived from bP1 were used to investigate the $5^{\prime}$ - and $3^{\prime}$-UTRs of PTHrP transcribed in lactating bovine mammary tissue. Primer P84 (5'-GGT TGG AGT AGC TGA TTC- $3^{\prime}$ ) corresponding to nucleotides within the exon 4-like region of bP1 and primer P82 (5'-GCA CCG AGT AGC TCA GCA GG-3') were used to amplify a $108 \mathrm{bp}$ fragment containing part of the 5'-UTR. Primer P56 (5'-AGA GCA GCC ACT GAA GAC-3') and primer P54 (5'-CAG CAG CAC CAA GAT ACA- $3^{\prime}$ ) corresponding to nucleotides within the exon 9-like region of bP1 amplify a $456 \mathrm{bp}$ fragment containing part of the $3^{\prime}$-UTR.
Sense (5'-GAG ACG TTC AAC ACT CCT GC-3') and antisense (5'-GAG CTT CTC CTT GAT GTC AC-3') primers for bovine $\beta$-actin were based upon the published sequence of bovine $\beta$-actin lymphocyte cDNA (GenBank \# K00622) and amplify a fragment of $276 \mathrm{bp}$. All oligonucleotides were synthesized commercially (Integrated DNA Technologies).

\section{Reverse-transcription/polymerase chain reaction (RT-PCR)}

Total RNA $(1 \mu \mathrm{g})$ was reverse transcribed with $100 \mathrm{U}$ Moloney murine leukemia virus reverse transcriptase (Gibco-BRL) at $37^{\circ} \mathrm{C}$ for $30 \mathrm{~min}$ in buffer containing $0.5 \mathrm{mM}$ of each dNTP and $2 \cdot 5 \mu \mathrm{M}$ random hexamers. Complementary DNA was amplified using $1 \mathrm{U}$ Taq DNA polymerase (Gibco-BRL) in buffer containing $2 \mathrm{mM} \mathrm{MgCl}_{2}$ and $50 \mathrm{pmol}$ of each oligonucleotide primer. The PCR amplification was conducted for 40 cycles in a thermocycler (Perkin-Elmer-Cetus 9600 Gene Amp PCR System; Perkin-Elmer-Cetus, Norwalk, CT, USA) with a thermocycle profile of denaturation at $94{ }^{\circ} \mathrm{C}$ for $20 \mathrm{~s}$, primer annealing for $20 \mathrm{~s}$ at $60{ }^{\circ} \mathrm{C}$ and primer extension at $72{ }^{\circ} \mathrm{C}$ for $1 \mathrm{~min}$. PCR products were separated and visualized in a $2 \%$ agarose gel containing ethidium bromide. Total RNA isolated from lactating rat mammary tissue amplified with oligonucleotide primers P1 and P11 was used as a positive control for PTHrP. RT-PCR reactions omitting reverse transcriptase or RNA were used as negative controls. 


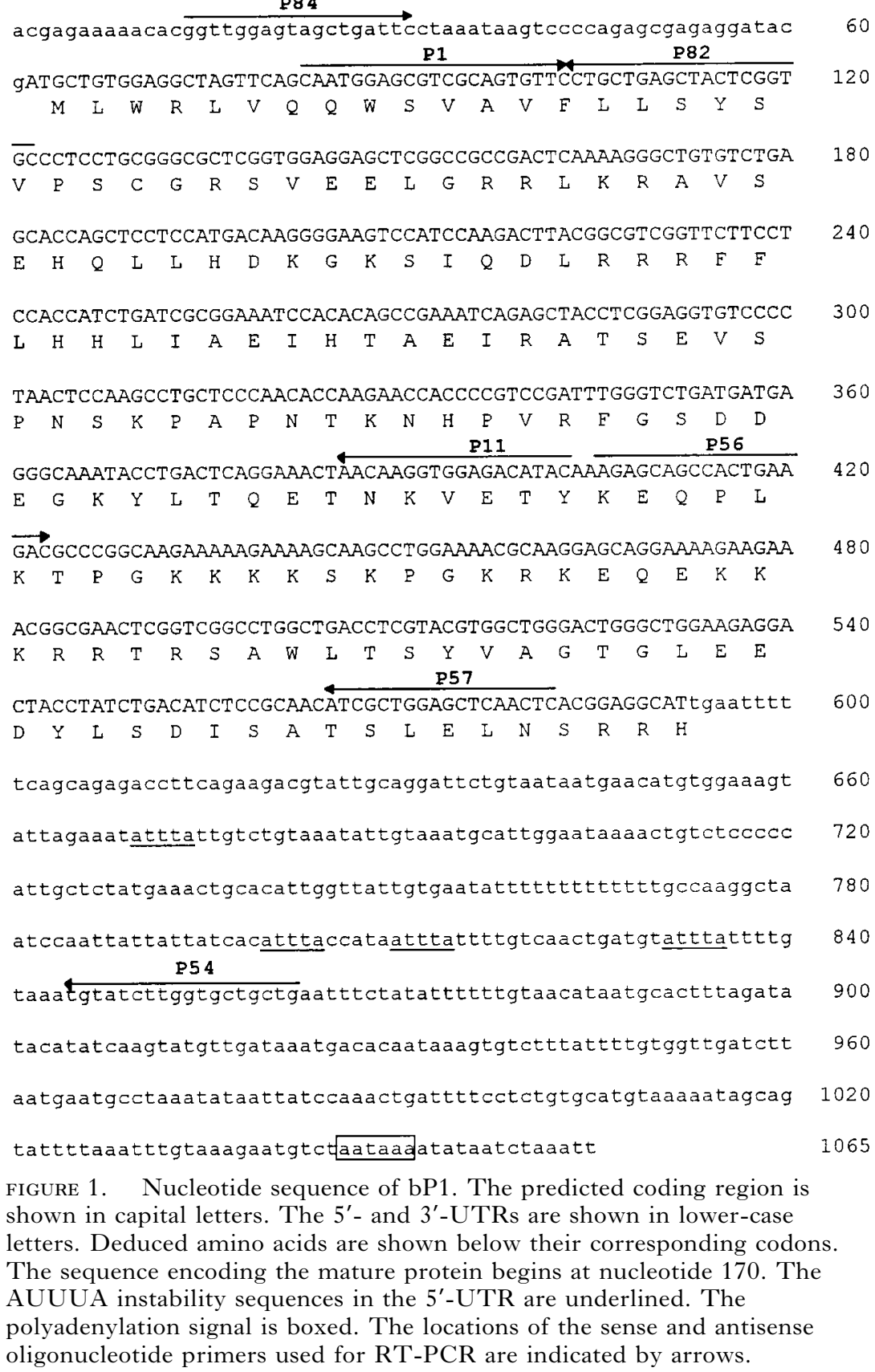

FIGURE 1. Nucleotide sequence of bP1. The predicted coding region is shown in capital letters. The $5^{\prime}$ - and $3^{\prime}$-UTRs are shown in lower-case letters. Deduced amino acids are shown below their corresponding codons. The sequence encoding the mature protein begins at nucleotide 170 . The AUUUA instability sequences in the $5^{\prime}$-UTR are underlined. The polyadenylation signal is boxed. The locations of the sense and antisense oligonucleotide primers used for RT-PCR are indicated by arrows.

\section{Southern blot analysis}

DNA from agarose gels was transferred to a nylon membrane (Duralon UV, Stratagene) by capillary action, hybridized overnight at $42^{\circ} \mathrm{C}$ in hybridization solution containing 500000 c.p.m. of either $\alpha-\left[{ }^{32} \mathrm{P}\right] \mathrm{dATP}$-labeled $434 \mathrm{bp}$ or $1066 \mathrm{bp}$ bovine PTHrP cDNA probe, washed at $37^{\circ} \mathrm{C}$, and exposed to $\mathrm{X}$-ray film overnight at $-80^{\circ} \mathrm{C}$ (Sambrook et al. 1989).

\section{Synthesis of riboprobes}

A PTHrP riboprobe corresponding to the common coding exon of human PTHrP (exon 6) was used to localize the PTHrP mRNA transcript in lactating bovine mammary tissue by in situ hybridization (Zhou et al. 1994). A 422 bp genomic PCR fragment corresponding to nucleotides +102 through +524 of the human PTHrP cDNA sequence (Suva et al. 1987) was subcloned into the EcoRI site of pAM-19 
(Amersham International, Buckinghamshire, UK) in both orientations. The plasmid was linearized with BamHI and transcribed by T7 RNA polymerase into antisense and sense riboprobes. The riboprobes were labeled with digoxigenin during RNA transcription using an RNA labeling kit (Boehringer Mannheim, Mannheim, Germany) according to the manufacturer's instructions.

\section{In situ hybridization}

In situ hybridization was performed on formalinfixed, paraffin-embedded lactating bovine mammary tissue as described (Zhou et al. 1994). Nonhybridized RNA was removed by treatment with $25 \mu \mathrm{g} / \mathrm{ml}$ of RNase A (Sigma Chemical Co., St Louis, MO, USA) in $2 \times$ SSC. To block non-specific binding of antibody used for detection, sections were incubated for $30 \mathrm{~min}$ in PBS containing 30\% normal rabbit serum, 3\% BSA, and $0 \cdot 1 \%$ Triton X-100 (Sigma). Hybridized probe was detected with alkaline phosphatase-coupled antidigoxigenin antibody (Boehringer Mannheim). Sections were counterstained with nuclear fast red. Sections used as negative controls were incubated either with sense riboprobe or treated with $100 \mu \mathrm{g} / \mathrm{ml} \mathrm{RNase} \mathrm{A}$ in $2 \times \operatorname{SSC}\left(2 \mathrm{~h}, 37^{\circ} \mathrm{C}\right)$ prior to prehybridization.

\section{RESULTS}

\section{Bovine PTHrP cDNA sequence and interspecies comparison}

The bovine brain PTHrP cDNA clone (bP1) was 1065 nucleotides (Fig. 1) and contained a 61 nucleotide $5^{\prime}$-UTR, an open reading frame of 531 nucleotides encoding a protein of 177 amino acids, and a 473 nucleotide $3^{\prime}$-UTR. The first 39 nucleotides of the $5^{\prime}$-UTR of bP1 were $80 \%$ homologous to the 3 '-region of human PTHrP exon 4 , suggesting that in the brain, bovine $\mathrm{PTHrP}$ is transcribed from a P3-like (downstream TATA promoter) promoter (Mangin et al. 1990b, Southby et al. 1996). Nucleotides 40-61 in the $5^{\prime}$-UTR of bP1 were $82 \%$ homologous to the untranslated sequences present in human PTHrP exon 5.

Comparison of the deduced bovine PTHrP amino acid sequence with sequences for human, mouse, rat, canine, and chicken PTHrP predicted a 36 amino prepro-region and a 141 amino acid mature bovine PTHrP peptide (Suva et al. 1987, Karaplis et al. 1990, Mangin et al. 1990a, Thiede \& Rutledge 1990, Rosol et al. 1995). Bovine PTHrP retains all putative di-, tri-, and multibasic proteolytic processing sites and the putative amidation sequences present at positions 86 and 94 that have been reported for human PTHrP (Orloff et al.
1994). Bovine PTHrP was 92, 90, 87, 85 and $72 \%$ homologous to canine, human, mouse, rat, and chicken PTHrP respectively (Fig. 2). Interspecies comparison of amino acids 1-111, which comprise the N-terminal and mid-region of PTHrP, demonstrated few conservative substitutions. Most of the amino acid sequence divergence was in the C-terminal region of PTHrP (amino acids 112-141). The 3'-UTR of bP1 was 473 nucleotides and had $96 \%$ sequence homology with the 3 '-UTR of exon 9 of the human PTHrP gene including corresponding positions for the polyadenylation signal and multiple AUUUA instability sequences (Mangin et al. 1990b, Southby et al. 1996).

\section{Identification and characterization of the bovine mammary PTHrP transcript}

A Northern blot (Fig. 3A) containing 10-30 $\mu$ g poly (A) + mRNA derived from lactating bovine mammary tissue was probed with $\alpha-\left[{ }^{32} \mathrm{P}\right] \mathrm{dATP}-$ labeled bovine cDNA (434 bp) corresponding to the coding sequence of PTHrP. A single 1200 nucleotide mRNA transcript for PTHrP was detected in lactating bovine mammary tissue.

RT-PCRs using region-specific oligonucleotide primers derived from the $5^{\prime}$ - and $3^{\prime}$-UTRs of bP1 were used to characterize the $5^{\prime}$ - and $3^{\prime}$-regions of mammary gland PTHrP mRNA. RT-PCR of total RNA from lactating bovine mammary tissue, using each of the oligonucleotide primer pairs depicted in Fig. 3B, amplified cDNAs of the expected sizes. Primers P1/P11 (lane 2, Fig. 3B) and P1/P57 (lane 3, Fig. 3B) amplified the expected $320 \mathrm{bp}$ and $499 \mathrm{bp}$ coding region fragments. Fragments of $108 \mathrm{bp}$ and $456 \mathrm{bp}$ were observed with primers P82/P84 (lane 4, Fig. 3B) and P54/P56 (lane 5, Fig. $3 \mathrm{~B})$ respectively, indicating that the same $5^{\prime}-$ and 3'-UTRs used in brain PTHrP mRNA are also used in mammary PTHrP mRNA. Southern blot analysis using $\alpha-\left[{ }^{32} \mathrm{P}\right] \mathrm{dATP}$-labeled bP1 (fulllength bovine brain PTHrP cDNA) probe demonstrated that these PCR products were PTHrPspecific (data not shown). The origin of the additional PTHrP-specific cDNAs amplified in lanes $4(300 \mathrm{bp})$ and $5(400 \mathrm{bp})$ is uncertain, but may be due to PCR artifact or amplification of genomic DNA. Amplification of human PTHrP genomic DNA with primers P82/P84 would produce a fragment of $270 \mathrm{bp}$ encoding portions of exons 4 and 5 as well as the intervening intron. The additional $300 \mathrm{bp}$ PCR product observed in lane 4 using primers P82 and P84 is consistent with an interpretation of genomic contamination although the genomic sequence of bovine PTHrP has not been reported. PCR products were not observed 


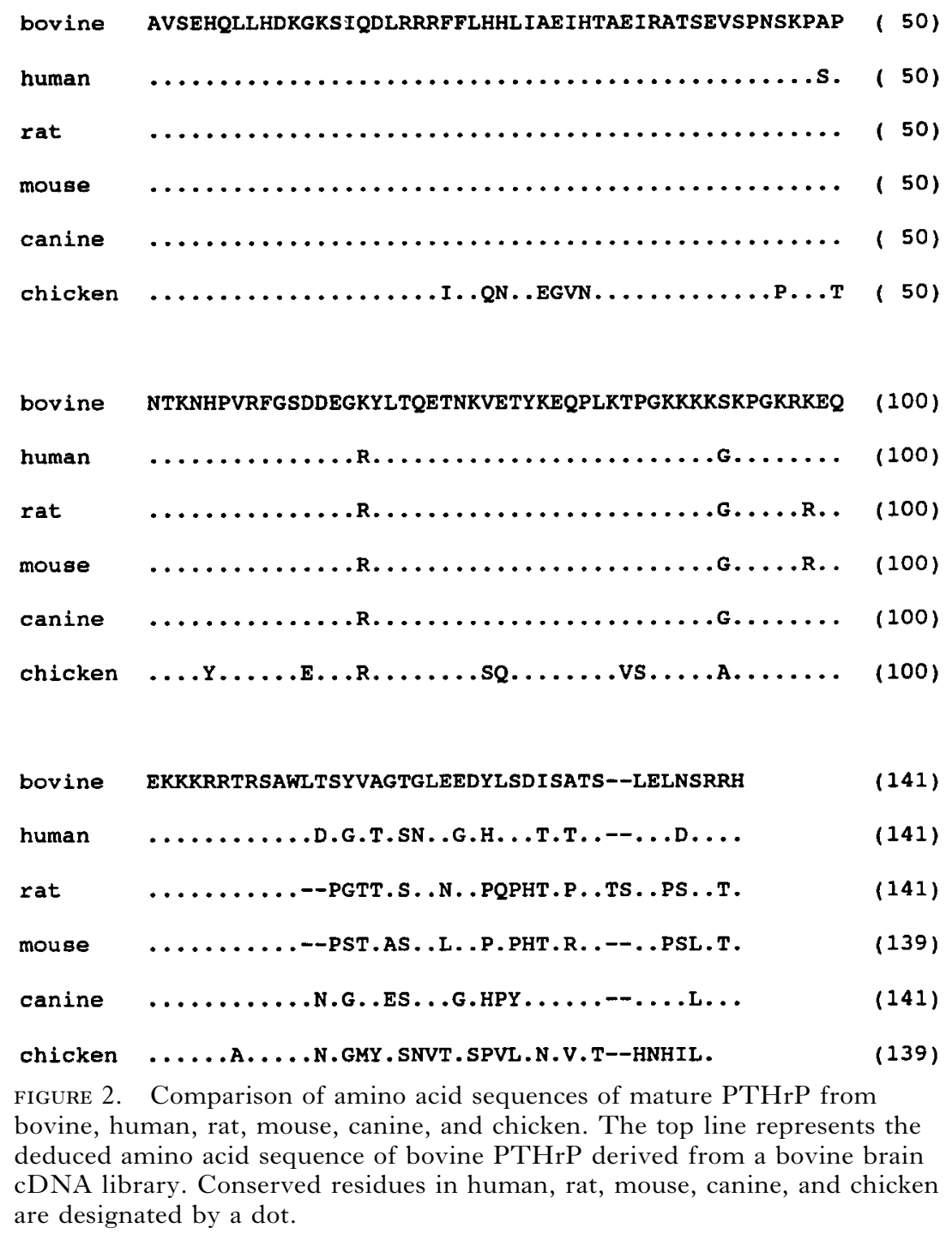

in RT-PCR reactions lacking RNA or reverse transcriptase.

\section{Expression of PTHrP mRNA in the bovine mammary gland}

The temporal expression of PTHrP mRNA in the bovine mammary gland was examined in nonpregnant heifers, pregnant heifers and cows during various stages of lactation using RT-PCR and Southern blot analysis (Fig. 4). PTHrP mRNA was expressed in the bovine mammary gland during late pregnancy and throughout lactation. Amplification of either a 320 or $499 \mathrm{bp} \mathrm{PTHrP-specific} \mathrm{RT-PCR}$ product was detected in one of two $(50 \%)$ heifers in the latter third of their first pregnancy, seven of eight (88\%) cows during early lactation ( $<100$ days), both of two $(100 \%)$ cows during mid-lactation (100-200 days), and both of two (100\%) cows during late lactation ( $>200$ days). In the single cow examined during the immediate preparturient non lactating period, PTHrP-specific RT-PCR products were not observed on agarose gels, but a faint signal was detected on Southern blots. Cow \#17 was 4.5 months pregnant with an embryo transfer calf and was not lactating for greater than 1 year. PTHrP mRNA was not detected in the mammary gland of this cow. In addition, PTHrP-specific RT-PCR products were not observed in the mammary gland of a non-pregnant, non-lactating heifer. Amplification of $\beta$-actin mRNA by RT-PCR confirmed the quality of the mRNA within the 

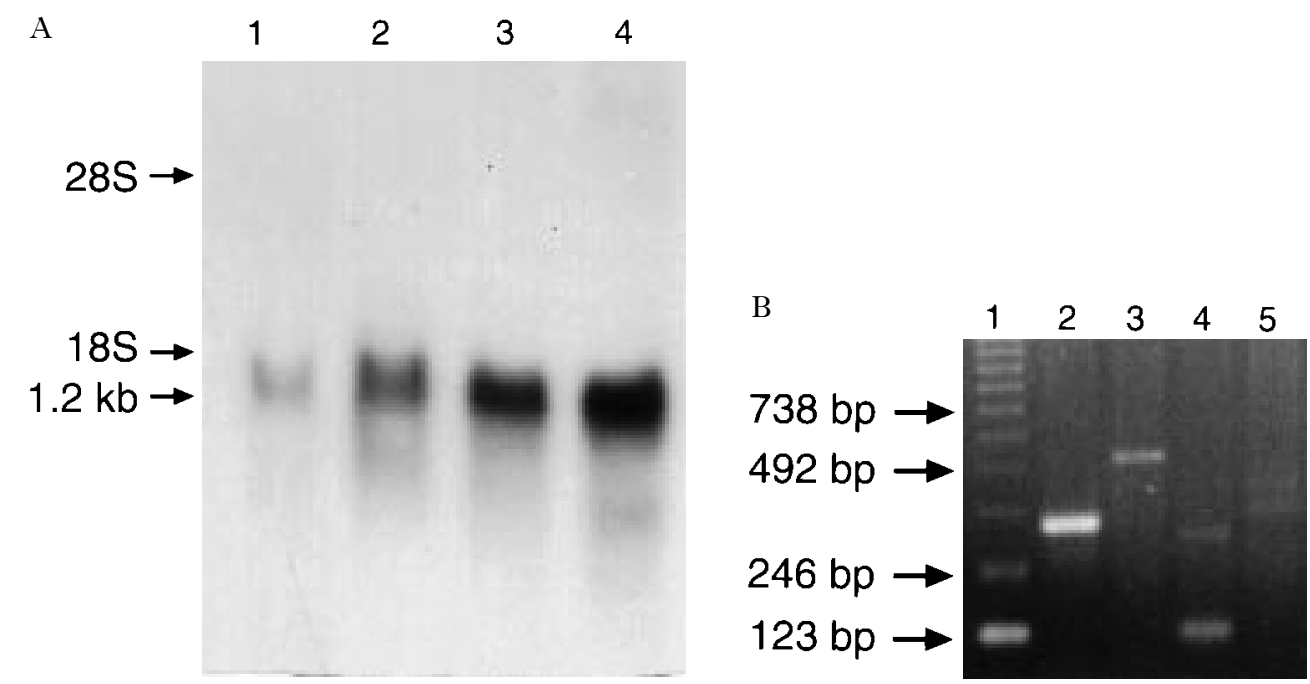

FIGURE 3. Characterization of bovine mammary PTHrP mRNA transcript. (A) Northern blot analysis. Lane 1, positive control, containing $10 \mu \mathrm{g}$ total RNA isolated from a canine apocrine adenocarcinoma. Lanes 2, 3, and 4 contain 10, 20, and $30 \mu \mathrm{g}$ respectively of poly $(\mathrm{A})^{+}$mRNA isolated from lactating bovine mammary tissue (cow \#9). Membrane was probed with $\alpha-\left[{ }^{32} \mathrm{P}\right] \mathrm{dATP}-$ labeled 434 bp bovine PTHrP cDNA. (B) Region-specific RT-PCR. Lane 1, 123 bp DNA ladder. Lanes 2-5, RT-PCR of $1 \mu \mathrm{g}$ total mammary RNA from cow \#9 using primers P1 and P11 (lane 2), P1 and P57 (lane 3), P82 and P84 (lane 4), and P54 and P56 (lane 5).

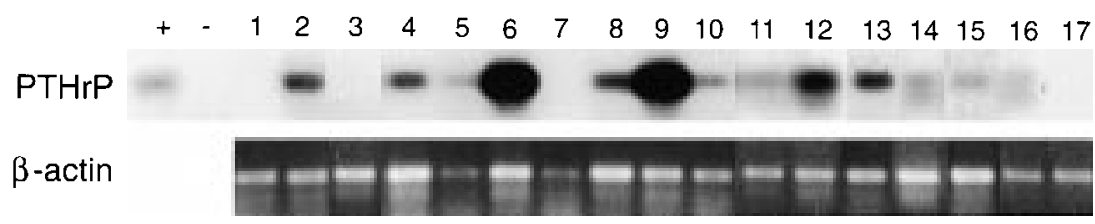

FIGURE 4. Expression of PTHrP mRNA in bovine mammary tissue in vivo. RT-PCR and Southern blot analysis for PTHrP. Total RNA was isolated from bovine mammary tissue at various stages of pregnancy and lactation, reverse-transcribed and amplified with primers for PTHrP or $\beta$-actin (lane numbers correspond to the cows' identification numbers in Table 1). PCR products were transferred to a nylon membrane by capillary action and probed with 500000 c.p.m. $\alpha-\left[{ }^{32} \mathrm{P}\right]$ dATP-labeled 434 bp bovine PTHrP cDNA. RT-PCR products for $\beta$-actin were visualized in agarose gels stained with ethidium bromide. Expression of RT-PCR products for $\beta$-actin confirmed the quality of RNA within the sample. Total RNA isolated from lactating rat mammary tissue amplified with oligonucleotide primers $\mathrm{P} 1$ and P11 was used as a positive control for PTHrP. RT-PCR of total RNA from lactating rat mammary tissue without using reverse-transcriptase was used as negative control.

samples. The temporal expression of PTHrP mRNA in the bovine mammary gland detected in this study is summarized in Table 1 .

In situ hybridization was used to localize the PTHrP mRNA transcript within the lactating bovine mammary gland. Positive staining for PTHrP mRNA was observed within most mammary alveolar and ductular epithelial cells (Fig. 5).

\section{DISCUSSION}

PTHrP produced by the mammary gland has been postulated to have important functions in both the mother and neonate (Thiede 1994). Multiple PTHrP peptides as well as intact PTHrP have been detected in both bovine and human milk (Budayr et al. 1989); however, the biologic significance of 


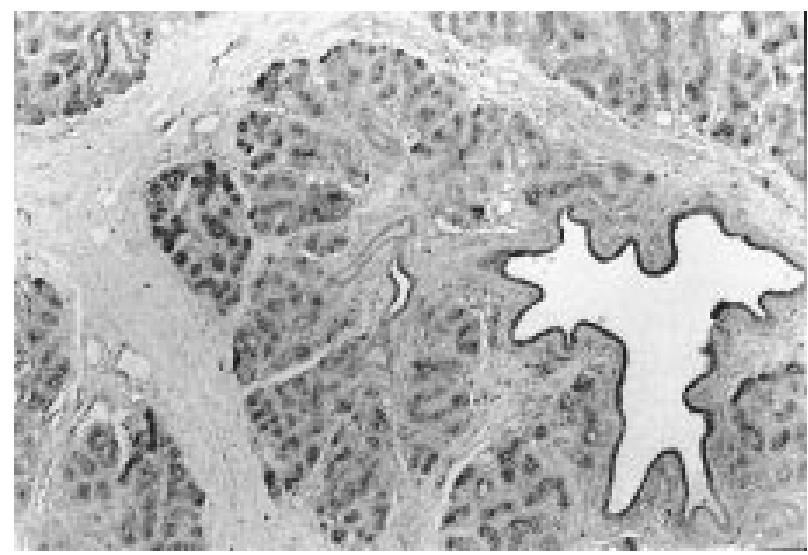

FIGURE 5. Cellular localization of PTHrP mRNA within lactating bovine mammary tissue using in situ hybridization. Formalin-fixed, paraffin-embedded sections of mammary tissue from a lactating cow were hybridized with 1-4 ng/ $\mu$ l digoxigenin-labeled PTHrP riboprobe for $16-18 \mathrm{~h}$ at $42^{\circ} \mathrm{C}$. Non-hybridized RNA was removed by treatment with RNase A. Hybridized probe was detected with alkaline-phosphatase coupled antidigoxigenin antibody. Sections were counterstained with nuclear fast red. Top panel: positive staining for PTHrP was detected in most alveolar and ductular epithelial cells. Bottom panel: negative control. Section was treated with RNase A prior to prehybridization.

these different molecular forms is uncertain. In other organs such as bone, different portions of the PTHrP molecule have been reported to cause different or opposing biologic effects (Kaji et al. 1995, Murrills et al. 1995, Seitz et al. 1995). The PTHrP peptides observed in milk could arise from multiple mechanisms including posttranslational endoproteolytic processing, extracellular proteolytic degradation, and alternative mRNA splicing.

The identification of a single 1200 nucleotide PTHrP mRNA transcript in lactating bovine mammary tissue which utilizes the same $5^{\prime}$ - and $3^{\prime}$-UTRs as the PTHrP transcript in brain suggests that bovine PTHrP has a genomic organization similar to that of the rat and mouse (Fig. 6). The mouse PTHrP gene contains at least four exons that are homologous to human exon 4 (5'-UTR), exon 5 (5'-UTR and prepro-region of PTHrP), exon 6 (the coding sequence of mature PTHrP), and exon 9 (3'-UTR) (Karaplis et al. 1990, Mangin et al. $1990 a$, Southby et al. 1996). In the rat, PTHrP is transcribed from a P3-like promoter located upstream from exon 4 and contains a single $3^{\prime}$ exon resulting in a 1500 nucleotide $\mathrm{PTHrP}$ transcript which has been detected in many tissues (Thiede \& Rodan 1988, Karaplis et al. 1990, Mangin et al. $1990 a$ ). In contrast, the human PTHrP gene is more complex consisting of nine exons with three promoters and alternative splicing of $\mathrm{mRNA}$ which result in multiple PTHrP mRNA transcripts (Southby et al. 1996). Direct evidence for alternatively spliced mRNAs in tissues from non-human species has not been reported. Our data suggest that the molecular heterogeneity of PTHrP observed in bovine milk does not result from alternative mRNA splicing.

The predicted sequence of mature bovine PTHrP (1-111) differs from human, rat, and mouse, and canine PTHrP by three or four amino acid residues. These substitutions occur at amino acids 49, 66, 92, and 98 and involve changes in either serine or basic amino acids which could potentially affect glycosylation or proteolytic cleavage of PTHrP. An O-linked glycosylated form of PTHrP has been detected in human keratinocytes but localization and significance of the glycosylation have not been determined (Wu et al. 1991). Amino acids 1-111 of chicken PTHrP contain multiple amino acid differences compared with mammalian PTHrPs; the biologic significance of these changes is unknown.

The C-terminal portion of PTHrP (112-141) is not highly conserved among reported species. The C-terminal region of bovine PTHrP is $30,43,50$, 67 , and $70 \%$ homologous to chicken, rat, mouse, human, and canine PTHrP respectively. The biologic function of the C-terminal PTHrP peptide is not clearly understood and may have divergent functions in different species.

PTHrP mRNA expression was demonstrated in the bovine mammary gland during late pregnancy and throughout lactation. The regulation of PTHrP mRNA expression in bovine mammary tissue is unknown. Although prolactin is not required for the maintenance of lactation in cows, serum prolactin is increased during lactation after milking and prolactin has been demonstrated to 


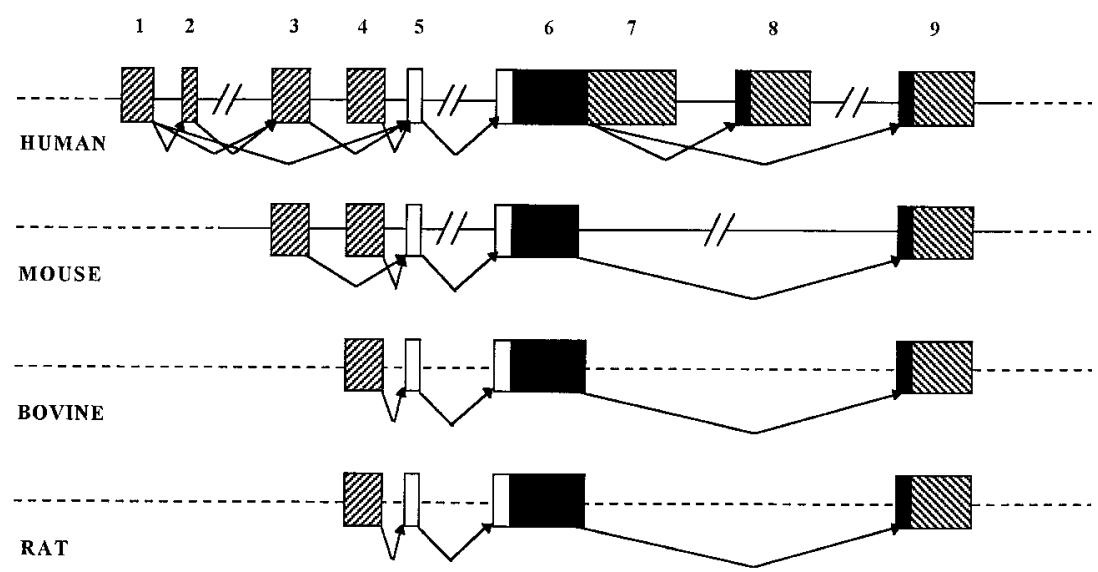

FIGURE 6. Comparison of the organization of the human and mouse PTHrP genes with the cDNA sequences of bovine and rat PTHrP. UTRs are shown in hatched boxes, the prepro-region is shown in white, and the coding sequence of the mature peptide is shown in black. Numbers correspond to exons of the human PTHrP gene. Arrows indicate observed and predicted mRNA splicing patterns.

increase production of PTHrP in bovine primary mammary cell cultures (Okada et al. 1996). These results are similar to in vivo findings in rats where transcription of PTHrP mRNA in the lactating rat mammary gland was stimulated by prolactin and was dependent upon suckling for continued expression (Thiede 1989). It is possible that milking regulates PTHrP expression by the mammary gland of ruminants since milking increased the concentration of PTHrP detected in the milk of goats (Thompson et al. 1994). Lack of milking for an extended period before tissue sampling may explain why PTHrP mRNA expression was not detected in 1 of 12 lactating cows in this study.

In summary, we have described the cloning and sequencing of bovine PTHrP and examined the expression of PTHrP mRNA within the bovine mammary gland. Analysis of the cDNA and amino acid sequences of bovine PTHrP and characterization of the mammary PTHrP mRNA transcript suggest that the multiple PTHrP fragments observed in bovine milk are the result of endoproteolytic processing or extracellular degradation of PTHrP, rather than alternative splicing of the PTHrP mRNA transcript. PTHrP synthesized within epithelial cells in the lactating mammary gland is the likely source of PTHrP observed within milk. The expression of PTHrP mRNA observed in the mammary gland of cows in this study is consistent with a physiologic role for PTHrP in both mammary development and lactation.

\section{ACKNOWLEDGEMENTS}

This work was supported by the National Institutes of Health (T J R; AR40220, AR01923: S F W; F32 DKO9294) and the United States Department of Agriculture Formula Funds to the Ohio State University College of Veterinary Medicine. The authors would like to thank $\mathrm{Mr}$ Bill Cox and the Food Animal Division of the Department of Clinical Sciences at the Ohio State College of Veterinary Medicine for generously providing bovine mammary tissue samples.

\section{REFERENCES}

Andersson Y, Lindquist S, Bergstrom S \& Hernell O 1997 Three variants of parathyroid hormone-related protein messenger RNA are expressed in human mammary gland. Pediatric Research 41 380-383.

Budayr AA, Halloran BP, King JC, Diep D, Nissenson RA \& Strewler GJ 1989 High levels of a parathyroid hormone-like protein in milk. Proceedings of the National Academy of Sciences of the USA 86 7183-7185.

Ikeda K, Mangin M, Dreyer BE, Webb AC, Posillico JT, Stewart AF, Bander NH, Weir EC, Insogna KL \& Broadus AE 1988 Identification of transcripts encoding a parathyroid hormone-like peptide in messenger RNAs from a variety of human and animal tumors associated with humoral hypercalcemia of malignancy. Fournal of Clinical Investigation 81 2010-2014.

Kaji H, Sugimoto T, Kanatani M, Fukase M \& Chihara K 1995 Carboxyl-terminal peptides from parathyroid hormone-related protein stimulate osteoclast-like cell formation. Endocrinology 136 842-848.

Karaplis AC, Yasuda T, Hendy GN, Goltzman D \& Banville D 1990 Gene-encoding parathyroid hormone-like peptide: 
nucleotide sequence of the rat gene and comparison with the human homologue. Molecular Endocrinology 4 441-446.

Khosla S, Johansen KL, Ory SJ, O'Brien PC \& Kao PC 1990 Parathyroid hormone-related peptide in lactation and in umbilical cord blood. Mayo Clinic Proceedings 65 1408-1414.

Kocabagli N, Riond JL, Spichiger UE \& Wanner M 1995 Parathyroid hormone-related protein and calcium homeostasis during the periparturient period of dairy cows. American Fournal of Veterinary Research 56 380-385.

Liapis H, Crouch EC, Grosso LE, Kitazawa S \& Wick MR 1993 Expression of parathyroid-like protein in normal, proliferative, and neoplastic human breast tissues. American Fournal of Pathology 143 1169-1178.

Mangin M, Ikeda K \& Broadus AE $1990 a$ Structure of the mouse gene encoding parathyroid hormone-related peptide. Gene 95 195-202.

Mangin M, Ikeda K, Dreyer BE \& Broadus AE $1990 b$ Identification of an up-stream promoter of the human parathyroid hormone-related peptide gene. Molecular Endocrinology 4 851-858.

Murrills RJ, Stein LS \& Dempster DW 1995 Lack of significant effect of carboxyl-terminal parathyroid hormone-related peptide fragments on isolated rat and chick osteoclasts. Calcified Tissue International 57 47-51.

Okada H, Schanbacher FL, McCauley LK, Weckmann MT, Capen CC \& Rosol TJ 1996 In vitro model of parathyroid hormone-related protein secretion from mammary cells isolated from lactating cows. Domestic Animal Endocrinology 13 399-410.

Orloff JJ, Reddy D, de Papp AE, Yang KH, Soifer NE \& Stewart AF 1994 Parathyroid hormone-related protein as a prohormone: posttranslational processing and receptor interactions. Endocrine Reviews 15 40-60.

Ratcliffe WA 1992 Role of parathyroid hormone-related protein in lactation. Clinical Endocrinology 37 402-404.

Ratcliffe WA, Thompson GE, Care AD \& Peaker M 1992 Production of parathyroid hormone-related protein by the mammary gland of the goat. Fournal of Endocrinology 133 87-93.

Rosol TJ \& Capen CC 1992 Mechanisms of cancer-induced hypercalcemia. Laboratory Investigation 67 680-702.

Rosol TJ, Capen CC, Danks JA, Suva LJ, Steinmeyer CL, Hayman J, Ebeling PR \& Martin TJ 1990 Identification of parathyroid hormone-related protein in canine apocrine adenocarcinoma of the anal sac. Veterinary Pathology 27 $89-95$

Rosol TJ, Steinmeyer CL, McCauley LK, Grone A, DeWille JW \& Capen CC 1995 Sequences of the cDNAs encoding canine parathyroid hormone-related protein and parathyroid hormone. Gene 160 241-243.

Sambrook J, Fritsch EF \& Maniatis T 1989 Molecular Cloning: A Laboratory Manual. 2nd ed. New York: Cold Spring Harbor Laboratory Press.
Seitz PK, Zhang RW, Simmons DJ \& Cooper CW 1995 Effects of C-terminal parathyroid hormone-related peptide on osteoblasts. Mineral and Electrolyte Metabolism 21 180-183.

Southby J, O’Keeffe LM, Martin TJ \& Gillespie MT 1995 Alternative promoter usage and mRNA splicing pathways for parathyroid hormone-related protein in normal tissues and tumours. British Fournal of Cancer 72 702-707.

Southby J, Murphy LM, Martin TJ \& Gillespie MT 1996 Cell-specific and regulator-induced promoter usage and messenger ribonucleic acid splicing for parathyroid hormone-related protein. Endocrinology 137 1349-1357.

Suva LJ, Winslow GA, Wettenhall RE, Hammonds RG, Moseley JM, Diefenbach-Jagger H, Rodda CP, Kemp BE, Rodriguez H \& Chen EY 1987 A parathyroid hormone-related protein implicated in malignant hypercalcemia: cloning and expression. Science 237 893-896.

Thiede MA 1989 The mRNA encoding a parathyroid hormone-like peptide is produced in mammary tissue in response to elevations in serum prolactin. Molecular Endocrinology 3 1443-1447.

Thiede MA 1994 Parathyroid hormone-related protein: a regulated calcium-mobilizing product of the mammary gland. Fournal of Dairy Science 77 1952-1963.

Thiede MA \& Rodan GA 1988 Expression of a calcium-mobilizing parathyroid hormone-like peptide in lactating mammary tissue. Science 242 278-280.

Thiede MA \& Rutledge SJ 1990 Nucleotide sequence of a parathyroid hormone-related peptide expressed by the 10 day chicken embryo. Nucleic Acids Research 183062.

Thompson GE, Ratcliffe WA, Hughes S, Abbas SK \& Care AD 1994 Local control of parathyroid hormone-related protein secretion by the mammary gland of the goat. Comparative Biochemistry and Physiology: Comparative Physiology 108 485-490.

Wu TL, Soifer NE, Burtis WJ, Milstone LM \& Stewart AF 1991 Glycosylation of parathyroid hormone-related peptide secreted by human epidermal keratinocytes. Fournal of Clinical Endocrinology and Metabolism 73 1002-1007.

Wysolmerski JJ, McCaughern-Carucci JF, Daifotis AG, Broadus AE \& Philbrick WM 1995 Overexpression of parathyroid hormone-related protein or parathyroid hormone in transgenic mice impairs branching morphogenesis during mammary gland development. Development 121 3539-3547.

Zhou H, Choong P, McCarthy R, Chou ST, Martin TJ \& Ng KW 1994 In situ hybridization to show sequential expression of osteoblast gene markers during bone formation in vivo. Fournal of Bone and Mineral Research 9 1489-1499.

REVISED MANUSCRIPT RECEIVED 29 October 1997 